\title{
An Empirical Study in Nepalese Commercial Bank's Performances on Green Banking: An Analysis From the Perspective of Bankers
}

\author{
Heena Tandukar ${ }^{I}$, Niranjan Devkota ${ }^{1 *} \odot$, Ghanashyam Khanal ${ }^{\circledR}$, \\ Ihtsham Ul Haq Padda ${ }^{3}$, Udaya Raj Paudel ${ }^{\circledR}$, Udbodh Bhandari ${ }^{1} \odot$, \\ Kabita Adhikari ${ }^{1}$, Seeprata Parajuli ${ }^{1}$
}

Quest International College, Pokhara University, Nepal

2 Morgan International college, Tribhuvan University, Kathmandu, Nepal.

3 Department of Economics, Federal Urdu University of Arts, Science, and Technology, Islamabad, Pakistan.

* Corresponding Author (niranjan@quest.edu.np)

Received: 22 October, 2020

Revised: 5 May, 2021

Accepted: 9 May, 2021

Published: 10 June, 2021

How to cite this paper:

Tandukar, H., Devkota, N., Khanal, G., Padda, I.U.H., Paudel, U.R., Bhandari, U., Adhikari, K., \& Parajuli, S. (2021). An empirical study in Nepalese commercial bank's performances on green banking: An analysis from the perspective of bankers. Quest Journal of Management and Social Sciences, 3(1), 49-62.

Copyright (C) 2021 by authors and Quest Journal of Management and Social Sciences.

This work is licensed under a Creative Commons Attribution-Non Commercial-No Derivatives 4.0 International License.

https://creativecommons.org/ licenses/by-nc-nd/4.0/

\section{Abstract}

Background: Becoming environmentally viable, lately, 'Going Green' has been a popular expression for both worldwide banking and financial areas just as for the overall population. Green banking as a piece of going green is another method of playing out the financial organizations thinking about the clean natural issues and corporate social duty of banks.

Objectives: This paper tries to investigate banker's overall arrangement and elements influencing their viewpoint on green banking performances.

Method: The information was gathered between June-October 2019 from various banks in Kathmandu valley, Nepal. The sample of 326 financial representatives has been gathered by utilizing a purposive sampling technique. Collecting primary and secondary data, this study utilizes an explanatory research design that assesses the causal relationship among reliant and free factors. The paper utilizes descriptive and inferential techniques for assessment. For understanding green financial mindfulness of the bankers, an index has been calculated.

Result: The outcomes show that large numbers of the bankers are less mindful of green financial practices in their banks, while just $5 \%$ of respondents know about green banking practices. The Probit regression results uncover that education, preparing for green banking, fixed expense, client fascination, related parties' directions, and security of the climate have critical and constructive impacts on green financial practices in banks.

Conclusion: All in all, for the selection of green financial practices, most importantly, banks ought to provide training to their employees and offer effective online services to their clients.

Keywords: Environmental Sustainability, Green Banking Initiatives, Green Banking Practice Awareness, Probit Regression, Nepalese Commercial Banks

Paper Type: Research paper

JEL Classification: C83, D83, G21, L86 and Q55. 


\section{Introduction}

Green banking is a emerging concept associated with the protection of the environment and sustainable development in the field of financial institutions which is still in the early stage in many parts of the world (Trehan, 2015; Rai et al., 2019). In this regard, Tu \& Yen (2015) maintain that green banking as a new form of banking is playing an intermediary role between economic development and environment protection, and Yang et al. (2009) assert that e-banking service is supportive for the promotion of green banking. Hence, nowadays, banks have started considering green banking as a new way of coping with emerging environmental issues and to meet their corporate social responsibility (Islam and Das, 2013). More broadly, it will eventually help in safeguarding the planet and contribute to the achievement of sustainable development (Islam and Kamruzzaman, 2015).

Various efforts and initiatives have been taken by banks and other financial institutions which have led them to maintain green, environmentally friendly practices coupled with carrying out the carbonfootprint-reduction activities (Deka, 2015; Jha and Bhome, 2013; Bihari, 2010). Bangladesh Bank is the first financial institution to initiate the concept of green banking in a global context (Masukujjaman and Aktar, 2013). Similarly, in the Nepalese context, the first bank to introduce the green banking concept is Laxmi Bank (Mehta and Sharma, 2016). In such endeavors, banks are focusing on various environmental protection activities like promoting bicycles as emission-free means of transportation, offering attractive loan packages for environment-friendly products that reward the customer for ecofriendly practices (Mehta \& Sharma, 2016). Regarding the condition for loan disbursement Bihari (2011) evidenced the Indian version of green banking that started with the objective of protecting the environment and these banks have set the environmental safety standards to be followed by all clients for the eligibility of receiving the loan. More importantly, Gupta (2015) states that the green banking system has many benefits as its products help to reduce paper consumption and protect the environment. Moreover, Tu \& Yen (2015) have further argued that green banking practices in developing countries, as in Vietnam, is complemented by e-banking adoption for acquiring the maximum environmental benefits.

Rishal and Joshi's (2018) argument about green banking tools, techniques, and equipment helping in minimizing internal carbon footprints and external carbon emissions to safeguard the environment and Uddin and Ahmmed's (2018) assertion about investment in green projects for the sustainable development of financial institutions are noteworthy in this regard. In this sense, Sahoo and Nayak (2008) suggested the promotion of green banking practices in consideration of environmental and ecological aspects and talked about the "Green Channel Counter" to go ahead for innovation of "green bank'. This discussion is further substantiated by the viewpoint of Bhardwaj and Malhotra (2013), who also asserted for the green bank practices to be adopted by businesses and industries from an environmental perspective.

Moreover, Rajesh and Dileep's (2014) assertion about banks' direct and indirect role for ecological footprints is worth-pondering. Arumugam and Chirute's (2018) suggestions for the disbursement of loans on condition of the adoption of environmental aspects are some of the remarkable arguments with respect to green banking practices. For such practices, Afroz (2017) illustrated green banking case of Bangladesh, involving in the management of energy in effective and efficient ways and reduction of paper use within the banking premises. In such circumstances, to substantially support the discussion over the need and significance of green banking practices, Yajurvedi (2015) contented that such practice is the way how banks are competing through bringing changes in their operation pattern policy wise and Lalon (2015) furthered this viewpoint by contending that customers' attention can be tapped strategically in environmentally benefitting the society. In the context of Nepal, Risal and Joshi (2018) provide the precise evidence of Laxmi bank in green banking practice that has been facilitating customers through easy transaction; avoidance of customer counter delay, awareness on digitalization and easy financing and protection of environment. 
Green banking has been an emerging issue in today's context, which has attracted many researchers to make study in this area throughout the globe (Rai et al., 2019). But it is a grim fact that the issue of green banking is novel and very less explored in context of Nepal. Therefore, this paper offers an improved understanding on importance of adopting green banking in the banks of Nepal. This research aims to analyze the banker's perspective on green banking in the commercial banks of Kathmandu valley, Nepal.

Remaining part of the study is structured as follows: section 2 portrays the methods used in the study. Likewise, Section 3 unleashes result and data analysis, section 4 of the paper presents discussion and the final section concludes with recommendations.

\section{Review of Literature}

\section{Conceptual Framework}

The conceptual framework presented in figure 1 has been designed to meet the study objectives. Various models dealing with factors like pressure from stakeholders, environment concern, and minimization of risk and improvement of image show positive relation with the practices of green banking. Similarly, after reviewing various literatures different dependent and independent variables are identified that are concerned with adoption of green banking practices. The dependent variables are adoption of green banking, banks' environmental performance and understanding of green banking for different models. The environmental concern, potential for the profitability, energy efficient equipment, in-house green decoration, electronic transactions, green loan, risk minimization, paperless statements, green project, solar energy consumption, green policy, internet banking, pressure from stakeholders, mobile banking, green lending policy and environmental trainings are independent variables (Arshad et al., 2011; Sharma, 2013; Sharma et al., 2014; Sharifi \& Hossein, 2015; Masukujjaman et al., 2017). It is common understanding of practice of green banking, which supports to reduce the extreme use of energy, power and paper (Risal and Joshi, 2018). Furthermore, green banking implies the bank without pollution through which it is possible to use environment friendly products and/or instruments (Mehedi et al., 2017; Rai et al., 2019).

\section{Figure 1: Conceptual Framework}

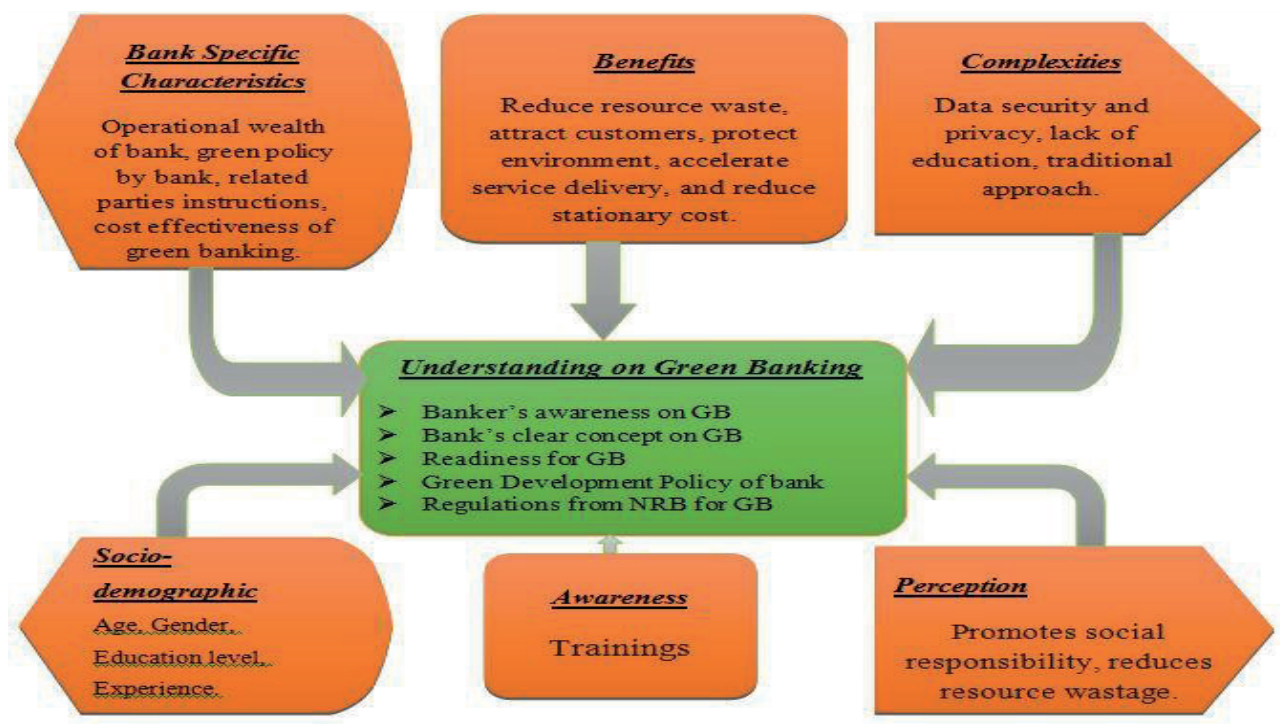


Source: Adopted from Mehedi \& Kuddus (2017) with some modification by authors.

For green banking practice to be adopted, it requires basic understanding of proper environment management, its strategies and policies (Mehedi and Kuddus, 2017). Similarly, Schub (2015) stated that green banks only invest on those projects, which are economical with proven technologies, loaners or project owners are being able to save money from reducing the carbon emission and energy savings.

Figure 1 presents various variables that can affect the general understanding of the bankers regarding green banking. After reviewing various articles related to green banking, the researchers have made the above study's conceptual framework based on ground realities (Arshad et al., 2011; Sharifi \& Hossein, 2015; Masukujjaman et al., 2017). The above conceptual framework includes the sociodemographic factors like age, gender, and work experience and education level of the respondents, which can affect their knowledge on green banking. Similarly, this study also deals with the awareness and perception of bankers which further incorporates sub-variables like know how, training, practices, existing technology, clear concept, readiness to adopt promotion of social responsibility, advocating cleanliness, reduces resource wastage, supported by government laws, and upholds ethics in business in green banking.

This study also concerns with determining factors of green banking practices. These practices include organizational pressure, environmental policy, operational wealth of bank, green policy by bank and related parties' instructions. Likewise, the above framework also includes the major benefit of green banking practices which can reduce resource waste, attract customers, covers CSR, protect environment, accelerate service delivery, reduces stationary cost, and raise profit. However, during the review of literature the researchers analyzed and found some complexities on the part of banks and financial institutions hurdling them in adopting and practicing green banking policies. These complexities include data security and privacy, lack of education, technical issues, traditional approach and lack of infrastructure. As this study is also related with the concept of reducing harmful resources and make the banking operations paperless, this framework has been designed to analyze the different dimensions related to the activities involved in adopting green banking practices in the banks.

\section{Empirical Framework}

Since acquiring of sustainable livelihood and mitigation of climate change problem is possible through green banking, it is essential to promote and popularize such banking practices through knowledge and information spreading to bankers and customers (Rai et al., 2019). However, green banking initiatives determine the way the bankers and customers perceive and adopt it (Shrestha et al., 2020). It is generally thought that people use green banking practices on the basis of net benefit they get from it (Mendelsohn, 2012). The theoretical framework presented in figure 1 suggests following model to find out the significant green banking determining factors by bankers.

Green Banking $(\mathrm{Y})=\mathrm{f}$ (socio-demographic factors, awareness, perception, bank specific characteristics, benefits, complexities)

For empirical results, regression analysis is done to ascertain variables influencing bankers understanding on green banking practices in bank. The research tries to take hypothesis in five different ways in commercial banks of Kathmandu Valley from the perspective of bankers. Following null hypotheses are to be tested against their alternative hypotheses:

$\boldsymbol{H}_{01}:$ There is no significant relationship between green banking awareness and given explanatory variables.

$\boldsymbol{H}_{02}:$ There is no significant association between bank's clear concept on green banking and given explanatory variables. 
$\boldsymbol{H}_{03}:$ There is no significant association between readiness for green banking and given explanatory variables.

$\boldsymbol{H}_{04}:$ There is no significant relationship between green development policies in bank and given explanatory variables.

$\boldsymbol{H}_{05}:$ There is no significant association between regulation from Nepal Rastra Bank (NRB) for green banking and given explanatory variables.

The dependent variable $(\mathrm{Y})$ is dichotomous variables, therefore, it can be written as: $\mathrm{Y}=\{1$ if bankers understand about green banking \& 0 otherwise $\}$. To measure the binary outcomes on dependent variables several questionnaire choices models, such as linear probability, logit and probit models can be estimated (Devkota et al., 2018). Out of these models, probit model, as the most common model, has been estimated in many of the studies. The literature has shown significant statistical properties with value of probability bound with 0 and 1 (Devkota and Phuyal, 2018). This study will use probit model by following Budhathoki (2017). Table 1 presents the variables used in this study.

Calculation of Bankers' Awareness Index: Several researchers like Biswas (2011), Amoako (2012), Bhal (2012), Islam and Das (2013) have signified the importance of green banking awareness by bankers. Bankers' awareness level can be measured by such index in terms of the initiatives of green banking and their understanding on practice of green banking polices. Based on the studies, this study has developed an index. This dummy-based index measures individual banker's awareness index as proposed by Devkota and Phuyal (2018). Total 13 different type of questions are asked to the respondents to understand their awareness level. 1 represents awareness and 0 for otherwise are included within this dummy based index.

Table 1: Description of Variables

\begin{tabular}{|c|c|c|c|}
\hline Variables & Description Value & Value & Expected Sign \\
\hline greenbanking_awareness & $\begin{array}{l}\text { Respondent's awareness on } \\
\text { green banking }\end{array}$ & $1=$ Yes, $0=$ No & \\
\hline yourbank_clearconcept_gb & $\begin{array}{l}\text { Your bank provides clear } \\
\text { concept on green banking }\end{array}$ & $1=$ Yes, $0=$ No & \\
\hline ready_gb & $\begin{array}{l}\text { Bank is ready to accept green } \\
\text { banking }\end{array}$ & $1=$ Yes, $0=$ No & \\
\hline gbp_inyourbank & $\begin{array}{l}\text { Green banking is practiced in } \\
\text { your bank }\end{array}$ & $1=$ Yes, $0=$ No & \\
\hline NRB_reg & $\begin{array}{l}\text { Regulations by Nepal Rastra } \\
\text { Bank on green banking }\end{array}$ & $1=$ Yes, $0=$ No & \\
\hline \multicolumn{4}{|l|}{ Socio- Demographic } \\
\hline age & Age of Respondent & In years & \pm \\
\hline Gen & Gender of Respondent & $1=$ Male, $0=$ Female & \pm \\
\hline Edu & $\begin{array}{l}\text { Respondent's level of } \\
\text { education }\end{array}$ & In years & + \\
\hline work_exp & Work experience & In years & + \\
\hline bank_give_any_training & Received any training & $1=$ if yes, $0=$ otherwise & + \\
\hline \multicolumn{4}{|l|}{ Perception } \\
\hline promotes_sr & $\begin{array}{l}\text { Bankers' think GB promotes } \\
\text { social responsibility }\end{array}$ & $1=$ if yes, $0=$ otherwise & \pm \\
\hline reduces_res_wastage & $\begin{array}{l}\text { Bankers' feel GB reduces } \\
\text { resources wastage }\end{array}$ & $1=$ if yes, $0=$ otherwise & \pm \\
\hline
\end{tabular}




\begin{tabular}{|c|c|c|c|}
\hline \multicolumn{4}{|c|}{ Bank specific characteristics } \\
\hline operational_wealth_bank & $\begin{array}{l}\text { Bankers' think GB practices } \\
\text { depend on the available } \\
\text { operational wealth of bank }\end{array}$ & $1=$ if yes, $0=$ otherwise & \pm \\
\hline green_policy_bank & $\begin{array}{l}\text { Green policy by bank is } \\
\text { important }\end{array}$ & $1=$ if yes, $0=$ otherwise & \pm \\
\hline relates_parties_inst & Related parties instruction & $1=$ if yes, $0=$ otherwise & \pm \\
\hline cost_effe_gb & $\begin{array}{l}\text { Bankers' think green banking } \\
\text { is cost effective }\end{array}$ & $1=$ if yes, $0=$ otherwise & \pm \\
\hline \multicolumn{4}{|l|}{ Complexities } \\
\hline data_sec_privacy & $\begin{array}{l}\text { Bankers' feel data security } \\
\text { and privacy is a challenge to } \\
\text { implement GB }\end{array}$ & $1=$ if yes, $0=$ otherwise & \pm \\
\hline lack_edu & $\begin{array}{l}\text { Bankers think lack of } \\
\text { education can provide } \\
\text { problem in adopting GB }\end{array}$ & $1=$ if yes, $0=$ otherwise & \pm \\
\hline traditional_app & $\begin{array}{l}\text { Bankers' think they are more } \\
\text { comfortable with traditional } \\
\text { approach }\end{array}$ & $1=$ if yes, $0=$ otherwise & \pm \\
\hline \multicolumn{4}{|l|}{ Benefits } \\
\hline red_resource_waste & $\begin{array}{l}\text { Bankers' think GB helps to } \\
\text { reduces resource wastage }\end{array}$ & $1=$ if yes, $0=$ otherwise & \pm \\
\hline att_cus & $\begin{array}{l}\text { Bankers' feel GB practices } \\
\text { can attract customers }\end{array}$ & $1=$ if yes, $0=$ otherwise & \pm \\
\hline protect_envn & $\begin{array}{l}\text { Bankers' think GB helps to } \\
\text { protect environment }\end{array}$ & $1=$ if yes, $0=$ otherwise & \pm \\
\hline acc_service_delivery & $\begin{array}{l}\text { Bankers' think GB helps in } \\
\text { accelerate service delivery }\end{array}$ & $1=$ if yes, $0=$ otherwise & \pm \\
\hline reduce_stat_cost & $\begin{array}{l}\text { Bankers' think GB can reduce } \\
\text { stationary cost of the bank }\end{array}$ & $1=$ if yes, $0=$ otherwise & \pm \\
\hline
\end{tabular}

\section{Study Area and Data}

The study area chosen for the study is Kathmandu valley. Kathmandu, Lalitpur and Bhaktapur districts are the three areas of the valley, which are located in Bagmati Province of Nepal. Kathmandu valley is the center for different major industries such as carpets, garments, finance, tourism, health, educational services, as well as, banking services. Shortage and lacking of service, and infrastructural development in many parts of Nepal have forced and made Kathmandu valley as a hub for many business and service activities. Present scenario shows the rapid growth of banking industry in Nepal. The study selected Kathmandu valley because many business activities occurs in this city area. Also, all 28 commercial banks operating in Nepal have their headquarters in Kathmandu valley.

This research is based on explanatory research design. Data from both primary and secondary sources were collected in order to get reliable and valid data. Questionnaire method was applied to collect the primary data using ground survey of the study area with selected commercial banks in Kathmandu valley. Secondary data has been used for strengthening research and its findings. The secondary data were gathered from articles, journals, annual reports of banks, publications of National Planning Commission (NPC), reports from the publication of Sustainable Development Goals (SDGs), books, newspapers, banking documents, electronic media, as well as published and unpublished documents 
of various research institutions. The employees from all $28 \mathrm{~A} \mathrm{grade}^{1}$ commercial banks operating in Kathmandu are the population for the study. The 326 sample were a relatively modest sample size drawn from the banks staff using non-probability sampling technique. The intended sample size of the study was 280 at $6 \%$ error.

\section{Data Analysis and Results}

For the analysis of data, both descriptive and inferential methods are used. Descriptive statistics along with frequency counts are applied to see whether there appears any error in the process of data entry and tabulation. Descriptive and inferential statistics are used for the study. As a part of study analysis probit regression analysis is performed for identification of statistically significant variables that determine the bankers' perception on green banking in study area.

\section{Descriptive Analysis}

The analysis reveals that two third of the bankers are above the age of 21 years, $22 \%$ of the respondents are between $31-40$ and $4.9 \%$ are between the age of $41-50$ years while only $2 \%$ respondents are above 51 years of age. The sex composition of the respondents shows that $51 \%$ are female and $49 \%$ are male. This suggests that the female bankers are almost equal to male bankers. Considering the educational background, the study indicates that many of the bankers have completed Masters degree. Regarding work experience of the respondents, study indicates that majority of the respondents have work experience of less than 10 years. However, male respondents expressed their greater work experience than female respondents. Regarding training input, only $10 \%$ of the bankers have received the green banking trainings and $90 \%$ bankers haven't. Among those $10 \%$ bankers who have received the green banking training, $64.52 \%$ of bankers have received the trainigs conducted by the banks whereas $12.90 \%$ of the bankers have received the training from outside, $22.58 \%$ have received from both office and ouside. According to the analysis, most of the bankers (57.06\%) are aware about the concepts of the green banking. However, $25.77 \%$ of bankers are unaware about this concept even their bank has the green banking services like, green initiatves, mobile banking, e-banking, etc. Majority of female respondents (34.05\%) think green banking is environmental banking and $28.53 \%$ male respondents also perceive the same. For such argument, Evangelinos et al. (2009) maintained that several banks are now in situation of implementing green banking to deal with contemporary challenges of environmental problem.

\section{Table 2: Descriptive Analysis}

\begin{tabular}{|l|c|c|c|c|}
\hline Variable & Mean & Std. Dev. & Min & Max \\
\hline greenbanking_awareness & .5613497 & .4969848 & 0 & 1 \\
\hline yourbank_clearconcept_gb & .2389937 & .427141 & 0 & 1 \\
\hline ready_gb & .3925234 & .4890746 & 0 & 1 \\
\hline gbp_inyourbank & .1732852 & .3791787 & 0 & 1 \\
\hline reg_nrb_gb & .1766667 & .3820236 & 0 & 1 \\
\hline Gen & .4907975 & .5006838 & 0 & 1 \\
\hline Age & 29.8589 & 6.848584 & 21 & 58 \\
\hline work_exp & 5.915644 & 6.34506 & 0.5 & 38 \\
\hline Edu & 2.542945 & .5893902 & 1 & 4 \\
\hline bank_give_training & .0650155 & .2469357 & 0 & 1 \\
\hline promotes_sr & .634375 & .4823593 & 0 & 1 \\
\hline
\end{tabular}

1 As Nepal Rastra Bank (NRB), there are currently 28 Commercial Banks (Class A) in Nepal. A grade is allotted to the Commercial banks with paid-up capital of NRs 8 billion ( $\approx$ USD 70 Million). 
Tandukar et al.: An empirical study in Nepalese commercial bank's performances on green banking: An analysis from the perspective of bankers

\begin{tabular}{|l|c|c|c|c|}
\hline Variable & Mean & Std. Dev. & Min & Max \\
\hline reduces_res_wastage & .79375 & .4052458 & 0 & 1 \\
\hline operational_wealth_bank & .5297806 & .4998965 & 0 & 1 \\
\hline green_policy_bank & .4576803 & .4989885 & 0 & 1 \\
\hline relates_parties_inst & .1473354 & .3549968 & 0 & 1 \\
\hline red_resource_waste & .7909408 & .4073471 & 0 & 1 \\
\hline att_cus & .4912892 & .5007973 & 0 & 1 \\
\hline protect_envn & .7735192 & .4192849 & 0 & 1 \\
\hline acc_service_delivery & .3937282 & .4894292 & 0 & 1 \\
\hline reduce_stat_cost & .5470383 & .498652 & 0 & 1 \\
\hline cost_effe_gb & .6969697 & .4603439 & 0 & 1 \\
\hline data_sec_privacy & .4734694 & .5003177 & 0 & 1 \\
\hline lack_edu & .6530612 & .4769705 & 0 & 1 \\
\hline traditional_app & .4979592 & .5010194 & 0 & 1 \\
\hline
\end{tabular}

Among various banking services, mobile banking (32\%) is the most common service that is being used by all the banks. Second mostly used service is online banking (27\%) followed by saving paper while the other are ethical banking, power supply equipment, remote deposits, use of solar energy, green checking account, green loan, green credit card, green saving accounts, green mortgage, and green money market accounts. Almost two third (62.27\%) respondents are aware that green banking provides significant benefit to the customers. In this sense, Meena (2003) argued about the benefits of green banking being observed in various dimensions in developing countries, such as avoidance of paper work; awareness campaign about environment; providing green bank loan in lesser rates; formation of environmental standard policy for lending. In our study, majority of the respondents (59.20\%) think green banking initiatives help in contributing sustainable development and 69.02\% think environmental conservation and sustainable growth in future are possible due to green banking initiatives. In this context, Rahman et al. (2013) argued that bank's day to day activities like green investment management, online and paperless deposit management, and other e-activities can lead bank to become greener. In survey research, out of total respondents, $41.10 \%$ respondents are aware about its benefits. Likewise, $57.98 \%$ respondents feel that green banking is important in terms of change in climate.

Technology is important factor for easy and smooth provision and adoption of green banking, which Yang et al. (2009) significantly discussed that empirically proven e-banking services are found helping banking institutions for a green banking solution coupled with other banking activities along with their role in eliminating physical and geographic boundaries. As per the perception of respondents the existing technology is not sufficient (33.74\%) to promote green banking while only $21.47 \%$ respondents feel that the existing technology in their bank is sufficient for promoting green banking. Similarly, regarding readiness for green banking, 38.65\% respondents are ready for green banking but $36.81 \%$ respondents are still confused in accepting green banking in their bank because of the lack of training and knowledge. For such confusion and dilemma of adopting green bank practice, Choudhury, Salim, Bashir and Saha (2013) sounded substantially for every bank's needs for participating in the new green product development process in today's intense national and global banking competition. Furthermore, the statistics also show some technical and administrative issues in implementing green banking in banks. According to the result, few many $(32.82 \%)$ respondents are not aware about any green development policy in their banks. Likewise, it is seen that $32.51 \%$ respondents are not aware about the Nepal Rastra Bank (NRB) regulations regarding green banking. 
Green Bank's policy and related parties' instruction along with organizational pressure, environmental policy and operational wealth are found to affect bankers' perception regarding green banking. $53.06 \%$ respondents have stated that environment policy can impact the perception of bankers, $44.78 \%$ respondents state that green policy by bank can impact the bankers thinking, $39 \%$ respondents chose operational wealth of the bank that can affect the bankers perceptions. Similary, 35.58\% and $14.14 \%$ respondents stated that organizational pressure and related parties' instruction respectively can affect the bankers perception regarding the green banking. In this context, Lymperopoulos et al. (2012) asserted about the importance of green marketing in contributing towards sustainable development

The results reveal that majority of respondents think there is need of green banking related trainings for employees for effective implementation of green banking polices and services. Similarly, it is found that the awareness among bankers and customers regarding green banking services are equally significant to improve the scope of green banking in various banks. Likewise, $25.76 \%$ respondents gave suggestions to widen the area of green banking in commercial banks and $22.61 \%$ think that there should be proper implementation of polices regarding green banking in their banks. In such circumstances, Masukujjaman et al. (2017) made his argument on the rationale of financial institution entering into green banking system due to two driving factors- increasing customer demands and greater environmental awareness. Furthermore, the recommendations like proper education, use of latest technology, provision of effective online services, reduction of paper consumption and initiation from NRB are suggested by respondents for promotion of such banking practices.

\section{Green Banking Awareness}

The age group in between 21-30 seems to be more aware as compared to other age groups of respondents. Majority (76.38\%) of respondents are less aware, however, $18.40 \%$ were moderately aware and $5.21 \%$ were highly aware about green banking in their respective banks. On the basis of gender, $42.02 \%$ female respondents are less aware about green banking as compared to male whom which $34.36 \%$ are less aware, $10.7 \%$ male are moderately aware whereas $7.67 \%$ female, respectively. The awareness index shows only $3.99 \%$ male and $1.23 \%$ female respondents are highly aware over the green banking practices in their banks. In this sense, Bahl (2012) also talked about benefit of green banking as increasing paperless work and business people's awareness, loan sanction with low interest rates and following of environmental standards. Further,work experience of the bankers can determine their awareness level about green banking practices in their banks. Out of 326 respondents, 74.54\% bankers have below 10 years of work experience and out of them, only 5.35\% are highly aware about green banking and $13.12 \%$ and $76.13 \%$ are moderately aware and less aware respectively about green banking.

Majority of respondents who completed master level are highly aware about green banking which means the education of an individual can increase their awareness level as well. In contrast to it, $77.08 \%$ respondents also holding masters degree are less aware about green banking. However it is so, Choudhury, Salim, Bashir and Saha (2013) sounded for every bank's needs for participating in the new green product development process in today's intense national and global banking competition. In our study, $21.85 \%$ of respondents show they have completed upto bachelors degree and are moderately knowledgeable about banking practices in their banks. The result of awareness level indicates that $76.38 \%$ respondents are less aware about green banking practices in their banks. Similarly, $18.40 \%$ respondents are moderately aware and only $5.21 \%$ respondents are highly aware about green banking practices. Therefore, the result shows that the awareness level of banker's is very low as more than $50 \%$ are less aware about green banking practices in their banks. Moreover, Chen et al. ((2018) have called banks as the conscious member of the society, which are aware of the environmental changes and can play crucial role to support the government efforts in reducing carbon emission through green banking practices. 


\section{Regression Analysis}

Regression is performed for binary outcome variables with probit regression. The dependent variables with two possibilities are binary outcome variables. In this study, the probit regression is performed to know the bankers' perception on green banking and to analyze its determinants. The probit regression results are presented in table 3 .

The first model of the study indicates that nine independent variables have significant relationship with green banking awareness. Six of the factors (education, bank giving trainings, related parties instruction, attention to customers, environmental protection and reduce stationary cost) had a positive relationship with green banking awareness. Whereas, three factors (operational wealth of banks, green policy by banks, accelerate service delivery) have negative significant relation with green banking awareness among the respondents. In such discussion, Rahman, Ahsan, Hossain \& Hoq (2013) reasoned six crucial spheres of activities for banks to be green- investment management, deposit management, housekeeping, development of human capital process, corporate social responsibility (CSR), and consciousness promotion among clients and general mass. The other variables are insignificant. The second model of the study estimates the relationship between bank's clear concept about green banking and other independent variables. It reveals that trainings provided by bank, operational wealth of bank, green policy by bank, green banking reduces resource wastage, data security and privacy, traditional approach, green banking protects environment, and lack of education are significantly related to bank's clear concept about green banking. There are five independent variables that are positively significant in model 2 and three variables are negatively significant. The variables named green banking protects environment, operational wealth of bank and data security and privacy, trainings provided by bank, green policy by bank are significant with bank's clear concept about green banking. However, the dependent variables i.e. green banking reduces resource wastage, lack of education and traditional approach are negatively significant with bank's clear concept about green banking. Further, Hossen et al. (2014) concerns about three aspects that the De-materialization, De-carbonization, and Demobilization in the day to day banking activities are the salient features of green banking as a part of e-commerce.

The relationship between the readiness for green banking and independent variables is explained presented in the third model. There are four variables that are significant with one dependent variable named readiness for green banking. It indicates that trainings provided by bank, perception that green banking protects environment and cost effectiveness are significant with readiness for green banking. However, one independent variable named green banking reduces resources waste is negatively significant with readiness for green banking. The fourth model of the study illustrates the relationship between awareness about green development policy in bank with other independent variables. The result presented in table 2 shows that six independent variables namely gender of respondent, educational level of respondents, trainings provided by bank, green policy by bank, lack of education and traditional approach are significant with green development policy by bank. Out of six significant independent variables, four of them are positively significant and two are negatively significant with dependent variable i.e. green development policy in bank. Gender, educational level, Green banking policy by bank and trainings provided by bank are significant with awareness about green development policy in bank. Likewise, lack of education and traditional approach are negatively significant with awareness of respondents on green development policy in bank. Moreover, in its overall frame of understanding, Goyal and Joshi (2011) significantly mentioned about green banking gaining cultural power, since social banking includes the concepts of humane and humanist in financial activities. 
Table 3: Analysis by Probit Regression

Variables

\begin{tabular}{|c|c|c|c|c|c|}
\hline Variables & $\begin{array}{c}\text { Model } 1 \\
\text { greenbanking } \\
\text { aware }\end{array}$ & $\begin{array}{c}\text { Model } 2 \\
\text { yourbank__ } \\
\text { clearconcept_gb }\end{array}$ & $\begin{array}{l}\text { Model } 3 \\
\text { ready_gb }\end{array}$ & $\begin{array}{c}\text { Model } 4 \\
\text { gdp_- } \\
\text { inyourbank }\end{array}$ & $\begin{array}{c}\text { Model } 5 \\
\text { NRB_Reg }\end{array}$ \\
\hline Gen & $\begin{array}{l}0.0763 \\
(0.185)\end{array}$ & $\begin{array}{l}0.325 \\
(0.200)\end{array}$ & $\begin{array}{l}-0.151 \\
(0.179)\end{array}$ & $\begin{array}{l}0.712 * * * \\
(0.247)\end{array}$ & $\begin{array}{l}-0.167 \\
(0.234)\end{array}$ \\
\hline Age & $\begin{array}{l}-0.0457 \\
(0.0280)\end{array}$ & $\begin{array}{l}0.0110 \\
(0.0301)\end{array}$ & $\begin{array}{l}0.00836 \\
(0.0281)\end{array}$ & $\begin{array}{l}0.0114 \\
(0.0382)\end{array}$ & $\begin{array}{l}0.0233 \\
(0.0359)\end{array}$ \\
\hline work_exp & $\begin{array}{l}0.00112 \\
(0.0305)\end{array}$ & $\begin{array}{l}-0.0115 \\
(0.0316)\end{array}$ & $\begin{array}{l}-0.0417 \\
(0.0290)\end{array}$ & $\begin{array}{l}-0.0299 \\
(0.0426)\end{array}$ & $\begin{array}{l}-0.0207 \\
(0.0372)\end{array}$ \\
\hline Edu & $\begin{array}{l}0.261^{*} \\
(0.156)\end{array}$ & $\begin{array}{l}-0.0230 \\
(0.166)\end{array}$ & $\begin{array}{l}0.0417 \\
(0.150)\end{array}$ & $\begin{array}{l}0.589 * * * \\
(0.210)\end{array}$ & $\begin{array}{l}-0.106 \\
(0.202)\end{array}$ \\
\hline bank_give_any_training & $\begin{array}{l}0.733 * \\
(0.401)\end{array}$ & $\begin{array}{l}1.085^{* * *} \\
(0.387)\end{array}$ & $\begin{array}{l}0.625^{*} \\
(0.352)\end{array}$ & $\begin{array}{l}0.999 * * \\
(0.441)\end{array}$ & $\begin{array}{l}-0.113 \\
(0.380)\end{array}$ \\
\hline promotes_sr & $\begin{array}{l}-0.227 \\
(0.193)\end{array}$ & $\begin{array}{l}-0.183 \\
(0.214)\end{array}$ & $\begin{array}{l}0.0806 \\
(0.195)\end{array}$ & $\begin{array}{l}0.223 \\
(0.284)\end{array}$ & $\begin{array}{l}0.371 \\
(0.246)\end{array}$ \\
\hline reduces_res_wastage & $\begin{array}{l}0.241 \\
(0.229)\end{array}$ & $\begin{array}{l}-0.0298 \\
(0.266)\end{array}$ & $\begin{array}{l}-0.193 \\
(0.227)\end{array}$ & $\begin{array}{l}-0.222 \\
(0.266)\end{array}$ & $\begin{array}{l}0.304 \\
(0.268)\end{array}$ \\
\hline operational_wealth_bank & $\begin{array}{l}-0.366^{*} \\
(0.213)\end{array}$ & $\begin{array}{l}0.495 * * \\
(0.212)\end{array}$ & $\begin{array}{l}-0.281 \\
(0.187)\end{array}$ & $\begin{array}{l}0.181 \\
(0.249)\end{array}$ & $\begin{array}{l}-0.649 * * * \\
(0.252)\end{array}$ \\
\hline green_policy_bank & $\begin{array}{l}-0.520 * * \\
(0.237)\end{array}$ & $\begin{array}{l}0.818^{* * *} \\
(0.246)\end{array}$ & $\begin{array}{l}0.230 \\
(0.205)\end{array}$ & $\begin{array}{l}0.584 * * \\
(0.269)\end{array}$ & $\begin{array}{l}-0.106 \\
(0.247)\end{array}$ \\
\hline relates_parties_inst & $\begin{array}{l}0.757 * * \\
(0.320)\end{array}$ & $\begin{array}{l}-0.0728 \\
(0.294)\end{array}$ & $\begin{array}{l}0.136 \\
(0.243)\end{array}$ & $\begin{array}{l}-0.303 \\
(0.340)\end{array}$ & $\begin{array}{l}1.031 * * * \\
(0.310)\end{array}$ \\
\hline red_resource_waste & $\begin{array}{l}-0.448 \\
(0.277)\end{array}$ & $\begin{array}{l}-0.877 * * * \\
(0.286)\end{array}$ & $\begin{array}{l}-0.600 * * \\
(0.254)\end{array}$ & $\begin{array}{l}-0.270 \\
(0.323)\end{array}$ & $\begin{array}{l}-0.214 \\
(0.309)\end{array}$ \\
\hline att_cus & $\begin{array}{l}0.412 * * \\
(0.206)\end{array}$ & $\begin{array}{l}0.233 \\
(0.207)\end{array}$ & $\begin{array}{l}-0.262 \\
(0.197)\end{array}$ & $\begin{array}{l}0.0935 \\
(0.241)\end{array}$ & $\begin{array}{l}0.234 \\
(0.232)\end{array}$ \\
\hline protect_envn & $\begin{array}{l}0.719 * * * \\
(0.245)\end{array}$ & $\begin{array}{l}0.527 * * \\
(0.266)\end{array}$ & $\begin{array}{l}0.494 * * \\
(0.233)\end{array}$ & $\begin{array}{l}-0.299 \\
(0.295)\end{array}$ & $\begin{array}{l}-0.583 * * \\
(0.257)\end{array}$ \\
\hline acc_service_delivery & $\begin{array}{l}-0.445^{*} \\
(0.249)\end{array}$ & $\begin{array}{l}-0.116 \\
(0.225)\end{array}$ & $\begin{array}{l}0.224 \\
(0.216)\end{array}$ & $\begin{array}{l}0.350 \\
(0.279)\end{array}$ & $\begin{array}{l}-0.523^{*} \\
(0.279)\end{array}$ \\
\hline reduce_stat_cost & $\begin{array}{l}0.388^{*} \\
(0.209)\end{array}$ & $\begin{array}{l}0.0326 \\
(0.236)\end{array}$ & $\begin{array}{l}-0.0855 \\
(0.208)\end{array}$ & $\begin{array}{l}0.287 \\
(0.261)\end{array}$ & $\begin{array}{l}-0.693 * * * \\
(0.254)\end{array}$ \\
\hline cost_effe_gb & $\begin{array}{l}0.210 \\
(0.227)\end{array}$ & $\begin{array}{l}0.0290 \\
(0.234)\end{array}$ & $\begin{array}{l}0.552 * * \\
(0.225)\end{array}$ & $\begin{array}{l}0.300 \\
(0.294)\end{array}$ & $\begin{array}{l}0.840 * * * \\
(0.312)\end{array}$ \\
\hline data_sec_privacy & $\begin{array}{l}0.122 \\
(0.197)\end{array}$ & $\begin{array}{l}0.478 * * \\
(0.203)\end{array}$ & $\begin{array}{l}0.0691 \\
(0.183)\end{array}$ & $\begin{array}{l}0.205 \\
(0.222)\end{array}$ & $\begin{array}{l}0.291 \\
(0.228)\end{array}$ \\
\hline lack_edu & $\begin{array}{l}-0.231 \\
(0.205) \\
0.101 \\
(0.213)\end{array}$ & $\begin{array}{l}-0.397 * \\
(0.224) \\
-0.615^{* * *} \\
(0.235)\end{array}$ & $\begin{array}{l}-0.134 \\
(0.201) \\
-0.291 \\
(0.197)\end{array}$ & $\begin{array}{l}-0.695 * * * \\
(0.239) \\
-0.739 * * * \\
(0.284)\end{array}$ & $\begin{array}{l}-0.345 \\
(0.228) \\
0.346 \\
(0.233)\end{array}$ \\
\hline Constant & $\begin{array}{l}0.788 \\
(0.866)\end{array}$ & $\begin{array}{l}-1.215 \\
(0.892)\end{array}$ & $\begin{array}{l}-0.186 \\
(0.827)\end{array}$ & $\begin{array}{l}-2.992 * * * \\
(1.158)\end{array}$ & $\begin{array}{l}-1.238 \\
(1.132)\end{array}$ \\
\hline Observations & 235 & 233 & 233 & 214 & 233 \\
\hline
\end{tabular}

Note: Robust standard errors in parentheses while $* * * \mathrm{p}<0.01, * * \mathrm{p}<0.05, * \mathrm{p}<0.1$. 
In the fifth model, the relationship between regulations by NRB for green banking and other independent variables is narrated. There are six independent variables i.e. operational wealth of bank, related parties instructions, green banking protects environment, green banking accelerates service delivery, green banking reduces stationary cost and cost effectiveness of green banking are significant with regulations by NRB for green banking. For such discussion over environment issue, Ginovsky (2009) remarkably stressed on initiating to launch green banking products to ensure environmentally friendly business. Here, in our study, the results show that there are significant relationship in which two independent variables are positively significant and remaining four variables are negatively significant. The dependent variable is positively significant with related parties' instructions and cost effectiveness provided by green banking. The operational wealth of bank and green banking reduces stationary cost are negatively significant with regulations by NRB about green banking. Similarly, green banking accelerates service delivery has negative significance with regulations by NRB about green banking. In terms of the interpretation of above mentioned model, Jha and Bhome (2013); Karunakaran (2014); Singh and Singh (2012) comprehensively argued that Green banking, also termed as ethical banking or a sustainable banking, though controlled by the same authorities, is operated with an additional agenda of protection of the environment.

\section{Conclusion and Implications}

The research is conducted in order to find out the bankers' perceptions over practices of green banking in commercials bank of Kathmandu Valley. Sustainable development in mitigating the institutional barriers and challenges of market for investment allocation is possible by the green banking practices (Uddin and Ahmmed, 2018). From the study, it is found that majority of the bankers have knowledge on such practices and the top most popular green banking practices in banks are mobile banking, online banking, saving paper, green saving account and ethical banking. Similarly, the result suggested that $38.65 \%$ of the bankers are ready for such banking practices in their banks. Likewise, respondents also provide some of the suggestions to improve green banking scope in commercial banks.

The implications from this study emerges for the bank owners to provide trainings to their employees about green banking, arrange proper education, take steps to reduce paper consumption, provide effective online services, create awareness about green baking among the bankers and encourage latest environmental-friendly technology. The result of awareness index shows that many of the respondents are less conscious on such green practices in their banks. The positive relationship between green banking awareness and education level of respondents, green policy by bank, related parties instructions, reduce wastage resources, protect government, accelerate service delivery, reduce stationary cost, and cost effectiveness of green banking are shown by the result of inferential statistics. Hence, we can make a clean argument that bankers' level of the awareness on green practices of bank can be increased if they are provided proper education and training about green banking.

\section{Conflict of Interest}

Author(s) declares no conflict of interest while preparing this article.

\section{References}

Afroz, N. N. (2017). Green banking initiatives of Islamic bank Bangladesh limited. Global Journal of Management and Business Research, 17(1), 1-8

Amoako, G. K. (2012). Improving customer service in the banking industry-case of Ghana Commercial Bank (GCB)-Ghana. International Business Research, 5(4), 134-139.

Anish, B. K., Mahato, A., Thapa, S., Rai, A., \& Devkota, N. (2019). Achieving Nepal's sustainable development goals (SDGs) by effective compliance of corporate governance. Quest Journal of Management and Social Sciences, 1(1), 50-72. 
Arshad, M., Aslam, S., Razi, A., \& Ali, S. A. (2011). A comparative analysis of Bankers perception on Islamic Banking in Pakistan. International Journal of Economics and Research, 2(4), 1-12.

Arumugam, D., \& Chirute, T. (2018). Factors determining the adoption of green banking amongst commercial banks in Malaysia. Electronic Journal of Business \& Management, 50-62.

Bahl, S. (2012). Green banking-The new strategic imperative. Asian Journal of Research in Business Economics and Management, 2(2), 176-185.

Bhardwaj, B. R., \&Malhotra, A. (2013). Green banking strategies: sustainability through corporate entrepreneurship. Greener Journal of Business and Management Studies, 3(4), 180-193.

Bihari, S. C. (2010). Green banking-towards socially responsible banking in India. International Journal of Business Insights \& Transformation, 4(1), 82-87.

Bihari, S. C. (2011). Green banking-socially responsible banking in India. The India Banker, 6(1).32-37.

Biswas, N. (2011). Sustainable green banking approach: The need of the hour. Business Spectrum, 1(1), 32-38.

Budhathoki, N. K. (2017). Climate change: perceptions, reality and agricultural practice: evidence from Nepal. South Asian Network for Development and Environmental Economics, 85.

Chen, Z., Hossen, M. M., Muzafary, S. S., \& Begum, M. (2018). Green banking for environmental sustainabilitypresent status and future agenda: Experience from Bangladesh. Asian Economic and Financial Review, $8(5), 571$.

Coalition for Green Capital (2016). Growing clean energy markets with green bank financing: White paper. Retrived from http://coalitionforgreencapital.com/wp-content/uploads/2015/08/CGC-Green-Bank-WhitePaper.pdf

Deka, G. (2015). Green Banking Practices: A Study on environmental strategies of banks with special reference to State bank of India. Indian Journal of Commerce and Management Studies, 6(3), 11-19.

Devkota, N., \& Phuyal, R. K. (2018). Adoption Practice of Climate Change Adaptation Options among Nepalese Rice Farmers: Role of Information and Communication Technologies (ICTs). American Journal of Climate Change, 7(2), 135-152.

Devkota, N., Phuyal, R. K., \&Shrestha, D. L. (2018). Perception, determinants and barriers for the adoption of climate change adaptation options among Nepalese rice farmers. Agricultural Sciences, 9(3), 272-298.

Evangelinos, K. I., Skouloudis, A., Nikolaou, I. E., \& Leal Filho, W. (2009). An analysis of corporate social responsibility (CSR) and sustainability reporting assessment in the Greek banking sector. In Professionals' perspectives of corporate social responsibility (pp. 157-173). Springer, Berlin, Heidelberg.

Ginovsky, J. (2009). Green banking-Inside and out. Community Banker, 1(1), 30-32.

Goyal, K. A., \& Joshi, V. (2011). A study of social and ethical issues in banking industry. International Journal of Economics and Research, 2(5), 49-57.

Gupta, J. (2015). Role of green banking in environment sustainability-A study of selected commercial banks in Himachal Pradesh. International Journal of Multidisciplinary Research and Development, 8(2), 349-353.

Hossain, M. Z., Ahmed, M., \& Nisha, N. (2015). Consumer attitudes and perception towards green banking in Bangladesh. Green Banking in Bangladesh and Beyond, 48-76.

Islam, A., \& Kamruzzaman, M. (2015). Green banking practices in Bangladesh. IOSR Journal of Business and Management, 14(4), 37-42.

Islam, M. S., \& Das, P. C. (2013). Green banking practices in Bangladesh. IOSR Journal of Business and Management, 8(3), 39-44.

Jha, N., \& Bhome, S. (2013). A study of green banking trends in India. International Monthly Referred Journal of Research in Management and Technology, 2, 127-132.

Jha, N., \& Bhome, S. M. (2013). A Study of CRM-As a Strategic Tool Adopted by Banks with Reference to Axis Bank in Thane City. Indian Journal of Applied Research, 3(5), 454-457.

Karunakaran, R. (2014). Green Banking-An Avenue to Safe Environment. Galaxy international Interdisciplinary Research Journal, 2(2).

Lalon, R. M. (2015). Green banking: Going green. International Journal of Economics, Finance and Management Sciences, 3(1), 34-42.

Lymperopoulos, C., Chaniotakis, I. E., \& Soureli, M. (2012). A model of green bank marketing. Journal of Financial Services Marketing, 17(2), 177-186.

Masukujjaman, M., \&Aktar, S. (2013). Green banking in Bangladesh: A commitment towards the global initiatives. Journal of Business and Technology (Dhaka), 8(1-2), 17-40. 
Masukujjaman, M., Siwar, C., Mahmud, M. R., \& Alam, S. S. (2017). Bankers perception of green banking: Learning from the experience of Islamic banks in Bangladesh. Geografia-Malaysian Journal of Society and Space, 12(2).

Meena, R. (2013). Green banking: As initiative for sustainable development. Global Journal of Management and Business Studies, 3(10), 1181-1186

Mehedi, S., \&Kuddus, M. A. (2017). Green Banking: a case study on Dutch-Bangla bank ltd. Academy of Accounting and Financial Studies Journal. 21(2), 1-20.

Mehedi, S., Kuddus, M. A., \&Maniruzzaman, M. (2017). The identification of bankers' perception toward indicators for the adoption of green banking in Bangladeshi scheduled commercial banks. Journal of Internet Banking and Commerce, 22(2), 2-18.

Mehta \& Sharma (2016).Customers' persistence for green banking in Nepal. Asian Journal of Research in Banking and Finance, 6(10), 30-44.

Mendelsohn, R. (2012). The economics of adaptation to climate change in developing countries. Climate Change Economics, 3(02), 1-21.

Rahman, M., Ahsan, M., Hossain, M., \& Hoq, M. (2013). Green banking prospects in Bangladesh. Ali and Hossain, Md. Motaher and Hoq, Meem, Green Banking Prospects in Bangladesh (June 2, 2013). Asian Business Review, 2(2).

Rai, R., Kharel, S., Devkota, N., \& Paudel, U. R. (2019). Customer's perception on green banking practices: A desk. The Journal of Economic Concerns, 10(1), 82-95.

Rajesh, T., \& Dileep, A. S. (2014). Role of banks in sustainable economic development through green banking. International Journal of current research and academic Review, 2(12), 136-141.

Risal, N., \& Joshi, S. K. (2018). Measuring green banking practices on bank's environmental performance: Empirical evidence from Kathmandu valley. Journal of Business and Social Sciences, 2(1), 44-56.

Sahoo, P., \& Nayak, B. P. (2007). Green banking in India. The Indian Economic Journal, 55(3), 82-98.

Schub, J. (2015). Green Banks: Growing clean energy markets by leveraging private investment with public financing. The Journal of Structured Finance, 21(3), 26-35.

Sharifi, O., \& Hossein, B. K. (2015). Green banking and environment sustainability by commercial banks in India. International Journal of Science Technology and Management, 4(11), 294-304.

Sharma, K. (2013). Green banking in India: A roadmap to success. IBMRD's Journal of Management \& Research, 2(1), 229-239.

Sharma, N., Sarika, K., \& Gopal, R. (2014). A study on customer's awareness on green banking initiatives in selected public and private sector banks with special reference to Mumbai. IOSR Journal of economics and finance, 28-35

Shaumya, K., \&Arulrajah, A. (2017). The impact of green banking practices on bank's performance: Evidence from Sri Lanka. Journal of Finance and Bank Management, 5(1), 77-90.

Shrestha, S., Devkota, N., Paudel, U. R., Bhandari, U., \& Parajuli, S. Bankers' Communication Know-how: An Analysis from Commercial Banks of Kathmandu Valley. Quest, 2(1), 80-99.

Singh, H., \& Singh, B. P. (2012). An effective \& resourceful contribution of green banking towards sustainability. International Journal of Advances in Engineering Science and Technology, 1(2), 41-45.

Tara, K., Singh, S., \& Kumar, R. (2015). Green banking for environmental management: a paradigm shift. Current World Environment, 10(3), 1029-1038.

Trehan, R. (2015). Green banking in India. Journal of Poverty, Investment and Development, 14, 27-32.

Tu, T. T. T., \& Yen, T. T. H. (2015). Green bank: International experiences and Vietnam perspectives. Asian Social Science, 11(28), 188.

Uddin, M. N., \&Ahmmed, M. (2018). Islamic banking and green banking for sustainable development: Evidence from Bangladesh. Al-Iqtishad Journal of Islamic Economics, 10(1), 97-114.

Wadhe, A. P., \& Ghodke, S. (2013). To Study Consumer Awareness and Perception towards Usage of Mobile Banking. IBMRD's Journal of Management \& Research, 2(1), 110-123.

Yajurvedi, N. (2015). Emerging trends in banking-Increasing role of information technology. Indian Journal of Applied Research, 5(10), 636-639.

Yang, J., Cheng, L., \& Luo, X. (2009). A comparative study on e-banking services between China and USA. International Journal of Electronic Finance, 3(3), 235-252. 